\title{
Management as an Academic Discipline?
}

\author{
Christian De Cock (University of Essex) \\ Damian 0’Doherty (University of Manchester)
}

in A. Wilkinson, S. Armstrong and M. Lounsbury (eds.). The Oxford Handbook of Management. Oxford: Oxford University Press.

\section{Interrupted Beginnings}

What remains to be said about 'management as an academic discipline'? And where are we to begin? We could begin with Whitley's (1984) oft-cited summary of the state of management research published in the $20^{\text {th }}$ anniversary issue of the Journal of Management Studies. Looking back to the establishment in the USA of The Institute of Management Sciences and its major journal Management Science, Whitley concluded that the goal of an integrated, coherent and relevant 'science of management' seemed, if anything, further away than it did in those halcyon 1950s, whilst duly noting an exponential growth of journals, publications, and management academics over those three decades. He also commented on the sense of disillusionment with what had been achieved whilst questioning the intellectual respectability of dominant modes of reasoning in business and management studies. In short, he saw a field "characterized by fragmentation, proliferation of diffuse and unconnected intellectual standards, goals, techniques and multiple interpretations of research results" (p.342).

The next thirty years offer an exemplary case study of plus ça change - an irony given the simultaneous desire to give management theory and research an effective presence as a discipline (De Cock \& Jeanes, 2006). Riven by endless debates on the respective merits of integration and solidification (e.g. Pfeffer, 1993; Van de Ven 1999) versus preserving distinctive research 'paradigms' (e.g. Van Maanen 1995; Westwood \& Clegg, 2003), and perennial anxieties about overcoming the conflicting demands of academic rigour and practical relevance to contemporary management practices (e.g. Hambrick, 1994; Hodgkinson \& Rousseau, 2009), management studies appears to be very much still in search of discipline. A recent editorial in the Academy of Management Review offered yet one more 'summing up' of management theory development and reiterated the by now well-rehearsed theme that "current management theories have failed to keep pace with changes in the size, complexity, and influence of modern organizations"(Suddaby et al., 2011: 237). The authors went on to suggest that "as a discipline, we have failed to develop our own theories", as "most of the theories used by contemporary management researchers were formulated 
several decades ago, largely in the 1960s and 1970s" (p.236). Suddaby and his colleagues concluded with a rallying call effectively exhorting management scholars to develop what they call "indigenous theories". Holt and den Hond (2013: 1590), in their first editorial of the European based Organization Studies, interpreted this as a call for the study of management "to be a discipline, to become a discipline, or to finally accept the consequences of aspiring to be one".

All this suggests that it is impossible to begin with a grandstand view of the discipline' as would be typical of a concluding chapter in a volume such as this. Inexorably, such a beginning would treat disciplinary debates as a progressive standing upon the shoulders of giants or the passing on of the intellectual baton. And yet, as in some never-ending athletics relay race, the finishing line of a proudly established 'management discipline' remains forever out of reach. If this is something we want to question we will therefore need to attempt something different in our chapter, guided by Walter Benjamin's injunction to practice a form of reading and writing that "brushes history against the grain" (Benjamin, 1999: 257 - Thesis VII). Practically this means we aim to render 'strange' that which has become too familiar and to produce effects by showing things that management scholars may realise they have ignored in the rather peculiar body of literature and practices that makes up 'management studies'. This 'producing of effects' means that we adopt a different style or tone of writing from the one with which most readers will be familiar as our chapter grapples with the reading of, and writing about, management as a discipline haunted by aporia and incoherence. How to grasp and work with this aporia forms the burden of this chapter. At times irreverent and ill-disciplined, we write on the understanding that discipline is the problem that management leaves as its legacy, but we also want to retain the importance of this legacy so that we can hold open the possibility of its invention, re-invention, displacement, or discarding. Of course this question and the performative tensions the question introduces (i.e. from where and how does one write about the question of discipline?) into writing is forgotten by most management studies, but the implications of this forgetting define precisely the nihilistic predicaments in which contemporary management finds itself. The chapter invites the reader to participate in a movement of enquiry that helps avoid an unwitting managerialisation of academic labour, a movement which takes us back into the necessity of a genealogical attention to our disciplinary origins - discipline thought at the intersection of memory and history, the public and the private. This studied form of enquiry and writing works to create a space from which we might extricate our implication in dominant systems of power/knowledge and better to prepare for the much heralded end(s) of man (Derrida, 1969) for which the coming ecological disaster often summarised as 'the time of the Anthropocene' (Crutzen and Stoermer, 
2000) can serve as a marker. In proceeding thus we risk contradiction of course, and so we attempt to write in a way that will compel reading (as opposed to absorption) - perhaps even a 'violent reading' in Blum's (1973) terms - and will appeal to readers who want to advance towards new questions, as opposed to those who demand simplistic conclusions that reassure and placate.

We have structured this chapter into four parts. Bookending the two central sections on 'histories' and 'critical history and 'post-disciplinarity' we have composed two sections - 'beginnings' and 'endings', where we play rather irreverently with the very notion of 'discipline': they are a deliberate attempt to stay clear of the traditional 'introduction' and 'conclusion' which tend to offer respectively a false impression of solid ground from where to start or arrive. In this spirit 'New beginnings' attempts to re-introduce the paper. In the second section we turn to the standard histories of 'management' and address their claims to provide tangible foundations and delimitations of the subject. Yet, through a close reading we find a predominantly historicist method (reading the past through the categories of the present) deployed in these histories, which means the research tends to reduce to tautology, marked by an absence of coherence and discipline. In the third section we turn to the genealogical mode of investigation of Foucault who offers an exemplary way out of these dilemmas whilst also showing the importance of a vigilant and permanent questioning of discipline. He teaches us that only an inventive transgression will generate the kind of post-disciplinary method of study that permits us to take the measure of 'management as a discipline'.

\section{(New Beginnings)}

So if beginnings and endings are always somewhat arbitrary, why not begin with a single sentence found on the very first page of the inaugural issue of the Journal of Management Studies, which itself points to a foundational human beginning: "Ever since Adam first appraised Eve human beings have been appraising one another" (Rowe, 1964:1)? It is a sentence that embodies an odd mixture of grandiosity and ambition - if not hubris - but also a restricted and narrow selfregarding reflexivity. Rowe's paper offers an attempt to appraise appraisals, or more strictly, narrates a report on an attempt to appraise appraisals, in a manner that might also resemble the formal experimentation or ludic-play associated with those most dangerous scholars of discipline: the French literary movement known as Oulip (Ouvroir de littérature potentielle, roughly translated as 'workshop of potential literature' - Becker, 2012). That the formal academic study of management could begin with such a complex tension between selfgenerating amplification and self-defeating paradox has not attracted the attention it deserves, no doubt - and here we risk ill-founded speculation and a 
lack of discipline - because the attempt to look straight into the eyes of a founding aporia risks blindness. To begin with appraisals might also attract those persuaded by dynamics of displacement and psychoanalytical projection to affirm a certain playing out of anxiety and insecurity. Not unsurprisingly then, by the time of the launch of the British Journal of Management in 1990 it seemed as if the community had given up any pretence at discipline, the opening editorial declaring the intentions of the journal to provide "an outlet for all types of research and scholarship on managerially oriented themes, [that] will especially welcome contributions of a multi-disciplinary or inter-disciplinary nature" (Otley, 1990:1 - emphasis added). What is not managerially oriented is left undefined and the possibility of a supra-disciplinary position of appraisal and judgment seems implied even though the exact contours and content of this additional position are left in abeyance. Beginning in confusion and incoherence may not appear to bode well for the subject of management studies and its disciplinary ambition...

Such beginnings may help explain the paradox evident in the treatment of 'discipline' in popular management texts, particularly in those written to introduce and prepare students for employment. On the one hand a survey of recent texts would suggest that discipline is not popular at the moment: long gone are the days of thrift, self-discipline and abstinence essential to the protestant work ethic and the spirit of capitalism as identified by Weber. The writing of Urwick, Fayol, and Taylor - with its militarized language of bureaucracy, spans of control, staff and line, reporting protocols, and office procedures- has been replaced with a fascination for 'thriving on chaos', informality and post-bureaucratic forms of organization, where management should learn how to 'first, break all the rules' (Buckingham \& Coffman, 2005). Discipline seems to have been replaced by intoxication with all things creative, thinking outside the box, knowledge leadership, emotional intelligence, and doing the rounds in the press at the moment - the so-called 'talent pipeline'. It is remarkable how the most popular student textbooks in management shy clear of discipline with an almost embarrassed silence. In Mullins (2013) for example, there is no chapter dealing specifically with discipline, only sporadic and arbitrary references to its use in management theory and practice. Huczynski and Buchanan (2013) provide even less space for the subject. And yet, on the other hand, discipline appears as an omniscient and ever-present term of reference in both Mullins and Huczynski and Buchanan. References to discipline multiply and proliferate as it appears in a diverse and motley range of subjects including pre-modern forms of management practices, more modern human resource policies and procedures, industrial relations disciplinary and grievance procedures, labour discipline, industrial discipline, work discipline, self- 
discipline, and the academic disciplines from which the hybrid subject of organisational behaviour is forged. Discipline would appear to be nothing if it is not a multiplicity of conceptual promiscuity and ill-discipline!

In what follows we are also attentive to the fact that despite these difficulties, discipline may be on the verge of a return, certainly when one broadens the scope to include business and management outside the boundaries of the US-UK axis of influence. If the rise of Japan stimulated the broadening of the business and management studies curriculum in the USA during the 1980s to include culture, anthropology, and an attention to religion and spirituality in business (Clegg, 2014), then the reassertion of a post-isolationist US expansionism might explain the reappearance of discipline as a more self-conscious subject of attention in Covey's (2013) hugely popular text. Written with a commitment to apostolic forms of Christianity, Covey asserts that 'Management is discipline', and he repeats this formula throughout his text, coupled with a constant reference to the importance of character and self-discipline. It is unfortunately a narrow and restrictive reading. For Covey discipline essentially "derives from disciple - disciple to a philosophy, disciple to a set of principles, disciple to a set of values, disciple to an overriding purpose, to a superordinate goal or a person who represents that goal" (p.157; emphasis added). If recent textbooks in management are unable to provide much clarity, telling us that discipline is both everywhere and nowhere, perhaps a turn to the historians is required.

\section{Histories: Towards the Inter-zone?}

In search of the origins of management we might expect historians to help define the practice and discipline of management; however, this is rarely the case. Pollard's (1965) The Genesis of Modern Management is widely regarded as a seminal publication that shows how management is a recent invention emerging only after the industrial revolution in the UK. One of his guiding preoccupations is that better management could have avoided some of the worst social and psychological consequences that accompanied rapid industrialisation over the period 1780-1830. In many ways it is a thesis written as an apologia for greater management expertise, but it becomes evident that, for Pollard, management is understood in the most general of terms, covering a range of particularities and differences whilst also extending into public policy and government regulation. In so doing, Pollard extends the scope of 'management' beyond any neatly defined contours and content. Management is identified, inter alia, as an output or outcome of particular political institutions (policy), a stratum of organizational administration, a form of workplace supervision in craft and manufacturing industries, a diffuse but immanent force that manages the economy, and a form of what we might call 'governmentality', namely those 
practices through which day-to-day party politics is conducted. As a consequence of this prolixity, it becomes difficult to identify something recognisably 'disciplined' in management. In contrast to Pollard, Chandler (1977) is more focused on what he calls the 'visible hand' of management and administration in large organizations which he charts through the so-called second industrial revolution of large capital intensive industries that helped develop the large M-form structure of organization. Yet, once again, distributed across this complex and sprawling form of organization, management designates the work of co-ordination and control conducted at the corporate level and more mundane operational and supervisory practices exercised in workshops and on 'shopfloors'. Historiological and ideological differences in the practice of historical scholarship further complicate the issue of definition, with management being understood by some as mere agents of capital, whereas for others management designates a novel and relatively autonomous domain of activity forced to mediate and reconcile the contradictory or antagonistic relation between capital and labour (Marglin, 1974; Littler, 1982).

The prodigious scholarship of John Child (1969) identified the emergence of a distinctively $20^{\text {th }}$ century British 'management movement', in what has now become a standard reference for studies of British Management: British Management Thought - A Critical Analysis. Child finds the strong influence of Quaker inspired businesses in the formation of something recognisably 'disciplined' in management thinking and practice. Sir William Mather, Joseph and Seebohm Rowntree, Charles Renold, and Edward Cadbury are considered the pioneers and early intellectuals that forged a set of management principles based on a mixture of paternalism, welfare provision, human relations, liberalpluralist industrial democracy, and an ethic of 'public service'. However, throughout his study Child is unable to really acknowledge the internal contradictions of this Quaker 'inspired movement'. The commitment to duty and public service, for example, alongside the championing of private profit and the freedom of the entrepreneur means that 'the foundations' are far from coherent or secure. Nor is there great emphasis placed on the disjunction between what was written and said in public, through trade journals and other commercial publications, and what might have been going on in practice in British factories and industries in the early $20^{\text {th }}$ Century. It has been left to other historians of Victorian and early twentieth century industry, for example, to chart the violence and degradation, the persistence of slavery and 'child-labour' associated with the management of workers in many industries (Branson \& Heinemann, 1971). From the brutal gang master on the dock (Morrison, 1984) to the scourge of miner's lung (Bloor, 2000), working conditions were often violent and dangerous and management an arbitrary physical force of authority and intimidation. 
A similar incoherence is evident in Wilson and Thomson's (2006) more recent history of the making of modern management that mixes elements from Williamson's transaction cost economics, Chandler's history of American management, Fligstein and 'environmental control', and schematic 'force-field diagrams' depicting driving forces that promote management and restraining forces that retard the advance of management as a professional expertise. It is perhaps no surprise that with such an eclectic range of influences Wilson and Thomson produce something that resembles the very subject matter of their study: the lack of anything resembling a coherent body of knowledge or practice. Indeed, they rapidly descend into circularity and tautology. A careful reading of their force-field diagrams reveals that the very same factors that are identified as 'driving forces' are also 'restraining forces'. At various points in their thesis they resort to the view that management is located within organization, or within a wider context that shapes and influences activities and behaviours, and thereby setting up the familiar sociological dualism that pits structural constraints as something that inhibits the formation of modern management and advanced 'managerial capitalism'. At the same time, however, management as a movement is described as a context-shaping activity itself. In explaining the relative success of American business 1890-1918, for example, Wilson and Thomson conclude that "the vast and relatively affluent domestic market provided the stimuli for these changes, as well as the reform of competition law in 1890" (p.88). Where did this affluent market come from if not by management design? Is not a large proportion of this growing domestic market made up of managers who are of course simultaneously consumers? Other driving forces they identify include: educational institutions, financial institutions, physical infrastructure, industrial structure, market structure, product market competition, organisational strategy and theory, orientation to change, and managerial techniques. This miscellany offers a veritable rival for Borges' famous entry on animals in his imaginary encyclopaedia1! The circularity and tautology could not be clearer. In an effort to explain the rise of management as a modern practice that embraces sophisticated methodologies and practices, Wilson and Thomson tell us that managerial techniques explain... well, managerial techniques! Essentially it is the

\footnotetext{
${ }^{1}$ In the essay The Analytical Language of John Wilkins Borges refers to a "certain Chinese encyclopaedia entitled Celestial Emporium of Benevolent Knowledge": "In its remote pages it is written that the animals are divided into (a) belonging to the Emperor, (b) embalmed, (c) trained, (d) suckling pigs, (e) sirens, (f) fabulous, (g) stray dogs, (h) included in this classification, (i) trembling as if they were mad, $(\mathrm{j})$ innumerable, $(\mathrm{k})$ drawn with a very camelhair brush, (l) others, $(\mathrm{m})$ which have just broken the pitcher, (n) which resemble flies from a distance (Borges, 1952/1973: 103)." Borges' excerpt from this fictive Chinese encyclopaedia is a parody that puts into question the very intellectual system it is meant to exemplify (cf. De Cock, 2000: 602).
} 
large, scale vertically integrated form of business that is prioritised as the master explanation for the rise of management, but the form of business - whether Sform, U-form or M-form - is precisely the outcome, partly, of managerial activity. This suggests, of course that we have to go beyond and outside the very historicised terms of 'business and management' in order to explain the rise (or not) of management. Yet, Wilson and Thomson, like Chandler and other mainstream historians of the discipline, are unwilling to consider the role of wider political economy, empire, slavery, genocide, etc.

Remarkably there is little attention devoted to the practices of management in either Child or Wilson and Thomson. At the very heart of their project is the study of management, but even after a careful reading of these texts the student keen to learn something more about the practices of management will be none the wiser. What is it then that managers do? Pollard (1965) shows that management was practiced and the title of 'manager' deployed and used prior to the efforts to codify or systematise practices into a set of principles or rigorous body of knowledge that might form the basis for a self-conscious managerial 'discipline'. But it is Dalton's (1959) Men Who Manage and Mintzberg's (1973) The Nature of Managerial Work that are often credited as the pioneering studies of day-to-day practices and activities of managers. In the memorable summary of Mintzberg, managers "were seldom able or willing to spend much time on any one issue in any one session" (p.33). Instead, their activities were fragmented and often incoherent, characterised by randomness and trivia and treated with episodic attention span, marked by constant interruption and the sense of incompletion and waste. Managers were also constantly assessing what it was that needed their attention, what was significant or insignificant, and what the likely ramifications and implications were of actions and decisions taken on the hoof or improvised for the purposes of moving onto the next interruption. At one time, management might have worked in an office, with the constant to-and-fro of people seeking entrance, telephones ringing, memos arriving, the humming of air-conditioning systems, the irritating flickering of the fluorescent lights, and the unpredictable wobble of a loose wheel never fixed on the executive desk chair. Today, in the office-less paper-less organization, we might expect that 'managers' still fail to observe timetables and schedules, but added to the fragmentation observed by Mintzberg, the manager today is increasingly mobile and in transit, responding to email on the go, feeding twitter accounts and browsing various other social media sites whilst existing in a dimension of being defined by disorientation and jet-lag in a veritable form of 'non-place' (Auge, 1995) or 'the interzone' (Burrell, 1997). 


\section{Critical History and Post-Disciplinarity}

There is no way of telling what may yet become part of history. Perhaps the past is still essentially undiscovered! So many retroactive forces are still needed! (Nietzsche, 1887/1974: 104/\#34)

One of the most significant bodies of research to have taken management as a discipline seriously is the work of those allied to industrial relations and labour process study. Where attention is focused on the policies and practices of management, management is seen as a bit part player of more extended systems and institutional ordering - as was enshrined in the UK through collective bargaining and the so-called liberal-pluralist consensus (Clegg, 1979). Here, discipline forms an explicit part of management practice, as in the management of grievance and disciplinary procedures: periodically, labour needs to be disciplined. Such a focus, however, has a tendency to restrict its analysis to a limited and circumscribed understanding of discipline, and can result in little more than a detailed chronicle of disciplinary procedures designed to regulate the employment relation. In more radical terms, discrete practices of management are understood to form part of a logic of 'managerialisation' that has been forged out of an increasing expropriation of areas of the employment relation previously 'regulated' or managed through trade unions or local craft based labour practices. A more generous treatment of discipline is also evident in variants of Marxist theses where 'discipline' is understood to form part of a dialectic of struggle between capital and labour (see Hyman, 1989), but one tempered by contradiction and unpredictability because of the countervailing pressures in the dynamics of employment relations that compel management to seek forms of commitment beyond disciplinary compliance (Edwards \& Whitson, 1989; Edwards, 2005). Labour process study has perhaps done most to advance the claims that management represents a dangerous ideological force in work organisations that works on behalf of capital to control, subordinate and degrade labour. If Braverman's (1974) Labour and Monopoly Capital helped promote a strawman of management, the industry of papers and edited collections that followed in its wake certainly rectified any lack of theoretical and empirical sensitivity (see Knights and Willmott, 1990; Thompson and Smith, 2010).

Beyond Marxism and critical theory, the introduction of the work of Michel Foucault to the study of management and the labour process has been of momentous import in opening up new ways of thinking about the discipline of management. Early advocates of Foucault tended to focus on his major study of the rise of the modern prison in Discipline and Punish which offered a fundamentally different and more expansive understanding of discipline than 
typical in industrial sociology (Foucault, 1979). Many took the 'fruits' of this study, however, in ways that did little more than apply a different set of metaphors and concepts to what remained a very traditional understanding of management and the labour process (Sewell and Wilkinson, 1992). Here management was understood to be driven by the overwhelming preoccupation with control, seeking forms of work and organisational design that 'deskilled' labour, and breaking jobs down into more standardised and repetitive tasks that were then also made more amenable to inspection and 'surveillance' - a key motif in emerging Foucauldian studies of the workplace (see also Knights, 1990; McKinley and Starkey, 1998). Many of course wondered what this added to the work of people like Goffman (1959), berating the Foucault-turn for its failure to acknowledge the importance of objective material conditions and the political economy of 'structural' features of work organization that constrained what action might be possible at the micro- or meso-level of management and organization (Edwards, 1990; Thompson, 1990). This is a gross misunderstanding of Foucault and the implications that follow a careful study of his work (Knights and Vurdubakis, 1994; Knights, 2002).

A first reading of Discipline and Punish certainly gives the impression that what Foucault was interested in was a detailed genealogy of emerging modern disciplinary practices as they became evident in the form of the prison. Considerable analysis was made of the 'panopticon', the all-seeing but occluded central tower with lines of sight down the main spokes of the aisles of prison cells. More sophisticated versions of labour process study saw that something more was going on in the book and picked up on the link between modern disciplinary practices and what Foucault had studied from Nietzsche, namely the birth of the modern human subject (Knights and Vurdubakis, 1994). Foucault was not interested per se in an empirical study or documentation of prison life or the practices of managing a prison population. In many ways the prison operates as a metaphor for Foucault's thesis, a theatrical mise-en-scène, and a concept that opens up a field of forces that converge and diverge around its central motif to make more tangible the complex history that explains the emergence of modern subjectivity. In Bentham's studies of the prison Foucault discovers something like the logic of modernity made manifest in an architectural 'blueprint' and it is obvious to him that this was never realised in its idealised form. Instead of any simple empirical claim, he deploys the prison partly as dramatis personae to distil and illustrate what were wider changes to the way in which societies operated. Indeed, it is the birth of the modern nation state, allied to the emergence of the modern social sciences, which is the dominant target of Foucault's historical research into discipline. His preoccupations are not with whatever might be made empirically of any particular prison or workplace. 
Foucault is preoccupied with the task of writing a history of the present; in other words he reconstructs a history of that which is present but largely 'unknown', or in some ways mundane or taken for granted - sexuality, schizophrenia, the classroom, for example - and in writing this history encourages his readership to see the contingency of the categories and arrangements in which we find ourselves, and the possibility that things could be different ${ }^{2}$. This is the critical, 'deconstructive' history that Foucault learns to practice after his reading of Nietzsche. To see a 'transversal' relation across these domains, to uncover an underlying 'episteme' of knowledge that organizes our thinking but which lies 'between' that which we can identify in the terms of an epistemology or ontology, or in his later work, to trace the 'genealogy' of an idea, is to show that what we cherish as our most noble truths or morals finds its 'origin' dispersed in a more contested and uncertain dimension of subjectification, not easily appropriated by knowledge or experience. Hence, the practice of history is a practice of freedom that compels one to excavate the disciplinary practices that have made us who we are and thereby 'enables one to get free of oneself' and 'to know how and to what extent it might be possible to think differently' (Foucault, 1992, pps. 8-9). In doing so Foucault invites us to think how the arbitrary so quickly and easily becomes the rule. This means that all knowledge is dangerous, and if all knowledge is perpetuated through practices - what he calls knowledgepractices - then we are all co-implicated in the unfolding of arbitrary 'logics' for which we have very little understanding of the likely 'systemic' outcomes. For example, we can never be certain that we might not become implicated in practices which may later be condemned as abusive, sexist, or misogynist. In this way he warned us to be wary of the seemingly innocuous and, thereby, helped invent new objects of political critique by making political that which had hitherto not been understood as a matter of political controversy.

To be able to do this meant that Foucault had to step outside the disciplinary boundaries of his own intellectual training. His inter- or post-disciplinary status is often the cause of considerable controversy as scholars try to establish whether he was, for example, a historian or a philosopher (Megill, 1987; O'Farell, 1989). The methods of Foucault's texts were also not explicit, except when institutional and collegiate pressures forced him to publish clarification

\footnotetext{
${ }^{2}$ Foucault (1966/1970) starts the preface to his Les Mots et Les Choses (The Order of Things) with a direct reference to the passage from Borges' fictive Chinese encyclopaedia we quoted earlier in order to emphasize the contingency of any categorisation and arrangement: "This book first arose out of a passage in Borges, out of the laughter that shattered, as I read the passage, all the familiar landmarks of my thought - our thought, the thought that bears the stamp of our age and our geography - breaking up all the ordered surfaces and all the planes with which we are accustomed to tame the wild profusion of existing things..."
} 
(Foucault, 1972). What he was up to in Discipline and Punish was the exercise of a new form of history, a method he had devised through a careful reading of Nietzsche on genealogy. As Deleuze (1988:24) wrote, Foucault never worried or had time to explain his methods; he just got on with things and did his historical studies where "analysis and illustration go hand in hand". This form of study and writing allowed Foucault to invent effectively a new topology of organization, one where power can be studied in the form of strategies and practices not yet organized or consolidated into established forms of property or state power, and prior to the separation of subject and object. This opened up a whole new terrain for historical research and encouraged scholarship to study practices that are simultaneously subject and object-making. In the images of prisoners in cells, bowing down in apparent supplication to the omniscient system of surveillance and control, Foucault also has in mind the hive of workers who man the modern bureaucratisation of knowledge, as embodied, for example, in the university. Hence, it is we who are disciplined and punished, co-implicated in the formation of the modern nation state, a form of social organization which is itself soon to be erased under pressure from its internal contradictions and upon which these knowledge practices have been built (Foucault, 1970). Following some of Foucault's work, Readings (1996: 169) already sees the university as a ruined institution, one that has lost its historical raison d'être and where gains in critical freedom are being achieved in direct proportion to the reduction in their general social significance. He thus exhorts us to think "what it means to dwell in those ruins without recourse to romantic nostalgia".

The scope and scale of this kind of thinking and research practice go beyond any of the customary ambitions of business and management history, industrial relations, or labour process study. For Foucault, we are 'disciplined' by that which is apparently the most innocent and mundane, by that which is in front of our very own eyes, but which nonetheless forms part of an extended chain of practices with far-reaching consequences. And here resides a clue to how, as knowledge workers, we are ensnared in power relations, participating in the production and reproduction of power and inequality, perhaps unbeknownst to ourselves. Power cannot be adequately studied as something which resides in the remote heights of sovereignty, 'the macro', objective laws of political economy, or the machinations of a military-industrial complex supported by the rationales of bourgeois legal-practice, all decipherable according to a kind of 'critical realist' analysis. It is not convincing to understand power as something under which we labour, forming an immense structure of oppression and domination. Instead, we might better treat power as something operating more immanently which circulates in complex relays through lateral networks that support a disparate set of 'microphysical' practices - even those most minute 
and perhaps obvious or apparently trivial elements of the everyday. This means that Foucault might invite us to think about the genealogy of our own citational practices as academics, and how academic authority is achieved through certain rituals and rites of passage (Czarniawska, 1998). He would ask how and why we even come to contemplate writing about management as an academic discipline. We have noted that in the histories of business and management studies, the object of study is very often confused with those resources that make possible the study - the method, in other words - hence producing circularity and tautology. These methods are akin to management techniques and we have already attempted to draw out how these 'management techniques' become both cause and effect of historical analysis through a close reading of Wilson and Thomson (2006). Wilson and Thomson are not untypical. Most studies that have sought to address the emergence of something 'disciplinary' about management thought and practice have tended to produce only very narrow and circumscribed accounts and remain essentially intra-disciplinary or selfreferential in nature. How to escape this tautology poses one of the most serious challenges for the study of something like discipline in management, or for the quest to identify what is disciplinary about management, which is also our task here.

In tracing the genealogy of something we call 'management', Foucault would examine the historical conditions of possibility that enabled 'management' to become a delimited self-evident object of study or practice. He would also show how 'subjects' were simultaneously created out of the very same conditions that created this object. It is interesting in this respect to consider what we might recognise to be 'managerial techniques' at work in historical scholarship. There are more casual analogies with management in the sense that research and writing necessarily involve a certain management of boundaries, a certain desire for control of material, a certain aspiration for promotion and career, in which the academic journal replicates in many ways the management report. The very collection and harnessing of 'raw materials', the keeping of records, the analysis and then synthesis of these materials into a coherent and digestible form that will 'sell'; all of this can rapidly lead to classic bureaucratization in which the equivalent of managers emerge as experts who enroll and control access to the academic field (O'Doherty, 2009). Beyond this, the contemporary institutional organization of research in universities and the funding arrangements that support the development of major research in the social sciences and humanities all implicate and construct the applicant and fund holder as a manager. One of the most 'managerial' consequences of these arrangements is the increasing demand to tell the funders what it is that one is going to find out. This philistine desire to know in advance is an equivalent of killing curiosity, controlling and 
inhibiting the creativity necessary to the genuine advance of knowledge. To encourage such progress one must have a far greater tolerance for uncertainty and 'unknowing' and to acknowledge that we are not entirely sure where the research might take us, nor what the 'results' might be. We could go further and suggest that managerial discipline is simultaneously constructed and extended by historical research that does not question its object ('management') - or at least this expansion and consolidation of discipline proceeds insofar as scholarship avoids treating the more originary questions we are sketching here. Here, of course, is where the Marxist labour process theorists find common ground with celebrants of the vitality and power of management.

To make some advance on our insights we need to trace how something like a 'discipline' is forged. Such a quest will take us into practices that precede the existing discourse of management and the categories through which it is understood, and into a space that is interstitial, somewhere in-between the knowledge disciplines and the contemporary social and political institutions with which we are familiar. Such transgression allows us to cut through the circular logic and mutual co-implication of subject and object, in which the answer is already contained in the disciplinary imposed question through which, so to speak, management asks itself about its own history. Hence, it is useless to explain the origins of the business school by studying the internal history of one institution (Wilson, 1992). The rise of the business school in the UK emerges out of a vast array of forces and interests, much of these international in nature, dating back to the post World War Two US-led reconstruction of Europe and the UK under the auspices of the Marshall plan and the later Anglo-American Council for Productivity. Such reconstruction served the 'interests' of the United States in helping to create markets and consumers for American industrial exports and to resist the perceived threat of Communism (Cooke, 2004). Much of this can in turn be understood as an extension of a more basic and underlying logic (some might say ideology) that saw the competitive pursuit of ever more material wealth as providing the best answers to more basic and perennial philosophical questions concerned with how we might 'live well'. This is all wrapped up in a complex assemblage of ancillary and supplementary forces that include dominant assumptions about 'the individual', community and society.

It is not just ideas in the abstract that inform the early development of management studies, but a whole series of practices, objects, artefacts and materials. If management arises because of coordination and supervisory problems associated with large scale factory production, in which people were taken out of the smaller domestic-based 'putting out' system of primitive manufacture, then it is important to note that factories could not have been built 
without cheap industrialised construction materials such as iron and brick that allowed large covered open spaces to be built. In this vein, there is also an important history of the stopwatch, the basic tool that facilitated the measurements and 'scientification' of management in the work of Taylor and his followers, to be written here (cf. Thompson, 1967). To explain the emergence of management involves the collection of all these heterogeneous materials and elements. It is vital here that we do not overlook any item, however seemingly minor, innocuous, or even irrelevant, but lay out the elements in a space of formal equivalence so that we might explore possible relations and lines of influence free of the historicist tendencies that read back into history from contemporary categories and classifications with its allied presuppositions about causality and the scale and priority of significance amongst the various possible explanatory elements. In such a display we simultaneously should give chance to the extraction of our own values and prejudices as they are made manifest in the reflexivity which attends such a process of discovery. How these values and prejudices stimulate the selection and interpretation of 'evidence' and lead to the exclusion of other possible explanations provides the possibility for raising the choice of values; and perhaps the possibility of the discovery or invention of new values. Indeed, it was perhaps the lesson of structuralism that, "when faced with a disciplinary project, a crucial way of situating that project is by considering what it is not, what it excludes" (Readings, 1996: 173).

In this short review we have travelled a long way in the quest to understand the discipline of management, and only in entering such a space of enquiry can we begin to discover possible answers to the question of origins and delimitations. But does the study or practice of management amount to 'discipline'? Is it possible to offer a definition of discipline? Historically, the establishment of the modern university was the institutional means by which the established and emerging professions made claims to a monopoly of competence and accreditation - in law and medicine, geography, history, and economics, but also in the sciences and sub-disciplines associated with biology, physics and chemistry. In the process each discipline sought jurisdictional boundaries for their claims to expertise (Weber, 2001). Each subject then inculcates its students into a venerable tradition and body of knowledge that is formative of certain intellectual skills. To be a disciplined scientist, for example, is to exercise a certain intellectual style which differs from that of the student disciplined into law or history. More than the shaping of minds, however, the experience of disciplinary inculcation is also one of being shaped in heart and mind, in body and soul. In this respect it is useful to recall that management might share affinities with the discipline of archery or even - as a recent study makes clear the arts of pencil sharpening (Rees, 2013)! Such an understanding of discipline 
more readily acknowledges the role of the body and its senses, and how these are often overlooked objects of the disciplinary process. This casts new light on that old maxim in which management is defined as 'paper pushers' and when asked what they do the old jokers reply 'sharpening pencils'! There are also of course the more widely recognized bodily techniques of business management and leadership: the handshake, the trained discipline of eye contact, the uniforms and pin-stripe suits, the particular tone with which one 'speaks' management, one's bodily comportment as one 'does' management, the collective arrangement of bodies and distance protocols observed in regular management meetings, etc. Only by virtue of their being commonplace have we forgotten their 'fantastical' qualities, arbitrary but ritualistic, culturally specific, and the distilled historical product of a long process of education and socialisation with its roots in manners and taste (O’Doherty, forthcoming).

\section{Endings (in the Anthropocene)}

Management provides no resource for how we might think and write about management as an academic discipline, and tucked away in the end chapters of an edited collection we seem to have been left in an impossible situation. Coming at the end, arriving always too late like Hegel's owl of Minerva, we are tasked to summarise and embrace the field of management studies in order to evaluate its disciplinary boundaries, to conclude with a definitive sign-off. But at the same time being part of this collection of essays, we appear to be implicated in the field in ways that make it impossible to delineate its outer boundaries. We are then simultaneously inside and outside, at the end - but announcing the necessity of beginning the enquiry again. We therefore oscillate on the edge of transgression. In many ways our predicament replicates (or mimics) that deconstructive logic we have found in management where it is compelled to assert or search for its own origins in a quest for disciplinary nobility. Yet, such an exercise at the same time undoes any claims to discipline, which as we have seen is performatively exemplified in the manner and style in which these studies are conducted. Within the corridors of the business school there certainly exists all manner of playful and creative transgressions that push the boundaries of management practice in ways that a mainstream eager to establish its credentials will find difficult and perhaps embarrassing. From human-dog telepathy (Reason, 1988: 189) to the latest methods and findings reported in the eminent Academy of Management Journal, including 'selective coupling as a response to competing institutional logics' (Pache \& Santos, 2013), 'compliant sinners' and 'obstinate saints' (Pitesu \& Thau, 2013) and 'endo- and exoisomorphism in corporate venture capital programs' (Souitaris, 2012), the ways and methods of management studies remain messy and heterodox. 
In this chapter we have been able to question the status of management as a legitimate object of intellectual enquiry and have even raised questions about the very possibility of a rigorous or disciplined study of management. In this way we followed Butler's (2009: 787) notion of critique as "not merely or only a sort of nay-saying, an effort to take apart and demolish an existing structure... [but] the operation that seeks to understand how delimited conditions form the basis for the legitimate use of reason in order to determine what can be known, what must be done, and what may be hoped". Given that management's 'disciplinary' status, composed of derivative and often awkwardly hybridised social sciences, remains contested in the business school, management might even be considered equivalent to Benjamin's (1999) concept of the whore of capitalism, she who accepts all petitions and enquiries. Discipline itself is far from disciplined in management studies and covers what could be described as a promiscuous range of subjects. Moreover, the historians struggle to convince that a self-conscious cadre of professional managers agrees on a core of disciplinary knowledge or expertise that has been accepted and put into practice by practitioners. Child's (1969) notion of a 'management movement' therefore lacks credibility, unless we conclude that such movement would have to be equivalent to that of the St Vitus dance.

In the light of what ethnographic studies reveal about the actual everyday practices of managers it seems a wishful fantasy to define management with the venerable and noble title of profession, let alone to grant it the status of discipline. However, as a reputational work of organization, 'management studies' has greatly assisted the development of a distinct labour market for business school professors who thus can claim the possession of academically certified skills and scholarly repute as key criteria for access to increasingly well paid jobs (Whitley, 1984). Furthermore, there can be no mistaking the data on applications to business and management studies degrees which have enjoyed a spectacular growth in recent years. It would seem that everyone wants to be a manager. Now the most popular subject at university, business and management is becoming ubiquitous and indeed synonymous with the university (O'Doherty \& Jones, 2005). Not only are there daily launches of new undergraduate programs and an expansion and proliferation of university business schools; everything in education is being constructed in the mirror image of business and management so that some speak of a 'managerialisation of everyday life' (Hancock \& Tyler, 2009). Even courses in theology and arts, for example, must be written in ways that can answer to the question of employability, as course tutors find themselves confronted by a vast impersonal technologically invested bureaucracy in which the encroachment of rules and regulations on things like course design means that 'content' is increasingly defined by management rather 
than on scholarly criteria or principles of academic merit. The 'infotainment' lecture or the reduction of knowledge to power-point presentations, the competitive individualistic culture of examination and accountability, and the requirement that lectures be motivational for students, are all examples of a greater managerialisation of higher education (Brown \& Carasso, 2013; Collini, 2012). You may be studying Latin in an Ivy League or Russell Group university but you are effectively being socialised into the ways and mores of management.

There seems to be something taking place that deserves the title 'disciplinary' though. When we hear students talk about the need to sex-up their CVs or downsize their facebook friendship list, leverage their grade point average or maximise their 'cost/income ratios', there is certainly evidence of disciplinary inculcation into a shared 'managerial' discourse. Students who have become expert in the understanding and practice of progression rules - with its volumes of governance structures made up of compensation, appeals, and mitigating circumstances - will all have become proficient in the logic of administration and litigation. Typically identified as 'game playing', this nonetheless probably offers a better grounding in how to succeed in contemporary business and management (see Lewis, 2014) than the ostensible subject matter of their degree, particularly if they have elected to formally study business and management. Managed and on-the-road-to-management, simultaneously subject and object, students today are being enrolled in a silent disciplinary apparatus that forges an ever-greater penetration of managerial logic.

To trace this disciplining we need to step outside the narrow confines in which most management academics ply their trade and explore practices that take place in-between and outside the established institutions of research and methodological discipline promoting management as a profession: in its endpapers, for example; its miscellanea and marginalia. Hence, we need to go beyond the relations that connect up powerful multinational global organizations, consultancies, business schools and degree curricula (Thrift, 2002). We might take courage from the fact that periodically editorials in major journals issue calls for greater daring and innovation (Holt \& den Hond, 2013; Suddaby et al, 2011), and even Feyerabend (1975) still receives the occasional name check. However, to cultivate a form of post-disciplinary practice that permits one to take a sideways glance at the historic forces shaping us as social actors and then to further delimit those disciplinary features which ensnare us in a restrictive form of management, demands a more transgressive practice as embodied perhaps in the work of Foucault. The implications that follow from Foucault (and allied advances in continental philosophy - e.g. Derrida, Deleuze and Guattari, Irigaray, Kristeva, Lacan etc.) compel experimentation with new 
ways of writing with all the attendant challenges this poses to the mutually constitutive interplay of societal power relations, inequalities, identity and insecurity. However, we might then begin to re-map and re-situate management in an extended ecology of objects and matter more relevant to the era of the Anthropocene. Assuming we survive, this will become the dominant problem for management in the future. Reader, you are likely to be baffled by this... but as innovative work, once on the edges of the social sciences, slowly makes its way into management we might anticipate that this re-situating of management will take the form of greater 'strategic partnerships' with a post-human ecology of plants, animals, stones, water, and even weather systems. Hoping to eclipse the all-too-human mindset, the challenge is formidable and will require a certain dedication to the ludic and - dare we suggest - a certain degree of discipline.

\section{References}

Augé, M. 1995. Non-places: introduction to an anthropology of supermodernity. London, Verso.

Becker, D. L. 2012. Many Subtle Channels: In Praise of Potential Literature. Harvard University Press.

Benjamin, W. 1999. Illuminations (H. Zorn, Trans.). London: Pimlico.

Bloor, M. 2000. The South Wales Miners Federation, miners' lung and the instrumental use of expertise, 1900-1950. Social Studies of Science, 30(1), 125-140.

Blum, A. F. 1973. Reading Marx. Sociological Inquiry, 43(1), 23-34.

Branson, N. \& Heinemann, M. 1971. Britain in the Nineteen Thirties. London: Wiedenfeld and Nicolson.

Braverman, H. 1974. Labour and Monopoly Capital. New York: Monthly Review Press.

Brown, R. \& Carasso, H. 2013. Everything for Sale? The Marketisation of UK Higher Education. London: Routledge.

Buckingham, M., \& Coffman, C. 1999. Break all the rules. New York. Simon and Schuster. Butler, J. 2009. Critique, Dissent, Disciplinarity. Critical Inquiry, 35(Summer): 773-795.

Borges, J. L. 1952/1973. The Analytical Language of John Wilkins. In J. L. Borges (Ed), Other Inquisitions: 101-105. London: Condor.

Burrell, G. 1997. Pandemonium: Towards a Retro Organization Theory. London: Sage. Chandler, A. 1977. The Visible Hand. Cambridge, MA: Harvard University Press.

Child, J. 1969. British Management Thought. London: George Allen and Unwin.

Clegg, S. 2014. Managerialism: Born in the USA. Academy of Management Review, online first.

De Cock, C. 2000. Reflections on Fiction, Representation and Organization Studies: An Essay with Special Reference to the Work of Jorge Luis Borges. Organization Studies, 21(3): 589-609.

De Cock, C. \& Jeanes, E. L. 2006. Questioning Consensus, Cultivating Conflict. Journal of Management Inquiry, 15(1): 18-30.

Collini, S. 2012. What are universities for? London: Penguin UK.

Cooke, B. 2004. The managing of the (third) world. Organization, 11(5), 603-629.

Covey, S. 2013 The 7 Habits of Highly Effective People, 25th Anniversary Edition. Simon and Schuster: New York.

Crutzen, P. J., \& Stoermer, E. F. 2000. The Anthropocene IGBP Newsletter, 41. Royal Swedish Academy of Sciences. Stockholm: Sweden. 
Czarniawska, B.1998. A narrative approach to organization studies. London: Sage.

Deleuze, G. 1988. Foucault. Minneapolis: Minnesota UP.

Derrida, J. 1969. The ends of man. Philosophy and Phenomenological Research, Vol.30, no.1: 31-57.

Edwards, P. 1989. The three faces of discipline, in Sisson, K. (Ed) Personnel Management in Britain. Oxford: Blackwell.

Edwards, P. K. 1990. Understanding conflict in the labour process: the logic and autonomy of struggle, in Knights, D. \& H. Willmott (Eds) Labour process theory. Houndmills: Macmillan.

Edwards, P. 2005. Discipline and attendance: A murky aspect of people management, in Bach, S. (Ed) Managing human resources, personnel management in transition. Oxford: Blackwell.

Edwards, P. K., \& Whitston, C. 1989. Industrial discipline, the control of attendance, and the subordination of labour: Towards an integrated analysis. Work, Employment \& Society, 3(1), 1-28.

Feyerabend, P. 1975. Against method: Towards an anarchistic theory of knowledge. Atlantic Highlands, NJ: Humanities Press.

Foucault, M. 1970. The order of things: An archaeology of the human sciences. London: Tavistock.

Foucault, M. 1972. The Archaeology of Knowledge. Pantheon Books.

Foucault, M. 1979. Discipline and Punish. New York: Vintage.

Foucault, M. 1992. The Use of Pleasure: The History of Sexuality Volume 2. Trans. Robert Hurley. Harmondsworth: Penguin.

Goffman, E. 1959. The presentation of self in everyday life. Garden City, NY: Anchor.

Hambrick, D. 1994. What if the Academy Actually Mattered? Academy of Management Review, 19(1): 11-17.

Hancock, P. \& M. Tyler, 2009 (Eds) The Management of Everyday Life. London: Macmillan.

Hodgkinson, G. P. \& Rousseau, D. M. 2009. Bridging the Rigour-Relevance Gap in Management Research: It's Already Happening! Journal of Management Studies, 46(3): 534-546.

Holt, R. \& den Hond, F. 2013. Sapere Aude. Organization Studies, 34(11): 1587-1600.

Huczynski, A. and Buchanan, D. 2013. Organizational Behaviour. 8 $^{\text {th }}$ Ed Harlow: Pearson Education.

Hyman, R. 1989 The Political Economy of Industrial Relations. London: Macmillan.

Knights, D. 1990 Subjectivity and the Labour Process, in Knights, D. \& H. Willmott (Eds) Labour process theory. Houndsmills: Macmillan.

Knights, D. (2002). Writing organizational analysis into Foucault. Organization, 9(4), 575-593.

Knights, D., \& Vurdubakis, T. 1994. Foucault, power, resistance and all that, in JM Jermier, D. Knights and W. Nord (Eds) Resistance and Power in Organizations. London: Routledge.

Knights, D. \& H. Willmott (Eds) 1990. Labour process theory. Houndsmills: Macmillan.

Latour, B. 2010. On the Modern Cult of the Factish Gods. Durham: Duke University Press.

Lewis, M. 2014. Flash boys: a Wall Street revolt. New York: WW Norton \& Company.

Littler, C. R. 1982. The development of the labour process in capitalist societies. London: Heinemann.

Marglin, S. 1974. What Do Bosses Do? Review of Radical Political Economy, 6, 33-60.

McKinlay, A., \& Starkey, K. (Eds).1998. Foucault, management and organization theory: From panopticon to technologies of self. London: Sage.

Mintzberg, H. 1973. The Nature of Managerial Work. New York: Harper and Row. 
Morrison, J. 1984 Stories of the Waterfront. Ringwood, Victoria: Penguin,

Mullins, L. 2013 Management and Organizational Behaviour. Harlow: Pearson Education.

Nietzsche, F. 1974. The Gay Science (W. Kaufman, Trans.). New York: Vintage.

O'Doherty, D. P. 2009. Revitalising labour process theory: a prolegomenon to fatal writing. Culture and Organization, 15(1), 1-19.

O'Doherty, D. P. forthcoming. Manners, Taste, and Etiquette: New Practices of 'Politesse' in Business and Management, in Beyes, T., Parker, M. \& Steyaert, C. (Eds) The Routledge Companion to the Humanities and Social Sciences in Management Education. Abingdon, Oxon: Routledge.

O’Doherty. D. \& C. Jones. (Eds) 2005. Manifestos for the Business School of Tomorrow. Dvalin Press.

Otley, D. 1990. Editorial. British Journal of Management 1(1): 1-2

Pache, A.C., \& Santos, F. 2013. 'Inside the Hybrid Organization: Selective Coupling as a Response to Competing Institutional Logics'. Academy of Management Journal, 56, 4, 972- 1001.

Pfeffer, J. 1993. Barriers to the Advance of Organizational Science: Paradigm Development as a Dependent Variable. Academy of Management Review, 18(4): 599-620.

Pitesa, M., \& Thau, S. 2013. 'Compliant sinners, obstinate saints: How power and selffocus determine the effectiveness of social influences in ethical decision making'. Academy of Management Journal, 56(3), 635-658.

Pollard, S. 1965. The Genesis of Modern Management: A Study of the Industrial Revolution in Great Britain. Harmondsworth: Penguin Books.

Readings, B. 1996. The University in Ruins. Cambridge (MA): Harvard University Press.

Reason, P. (Ed). 1988. Human inquiry in action: Developments in new paradigm research. London: Sage.

Rees, D. 2013. How to sharpen pencils. New York: Melville House.

Rowe, K. H. 1964. An appraisal of appraisals. Journal of Management Studies, 1(1), 125.

Sewell, G., \& Wilkinson, B. 1992. 'Someone to watch over me': surveillance, discipline and the just-in-time labour process. Sociology, 26(2), 271-289.

Souitaris, V., Zerbinati, S., \& Liu, G. 2012. Which iron cage? Endo-and exoisomorphism in corporate venture capital programs. Academy of Management Journal, 55(2), 477-505.

Suddaby, R., Hardy, C., \& Huy, Q. N. 2011. Introduction to Special Topic Forum: Where are the New Theories of Organization? Academy of Management Review, 36(2): 236-246.

Thompson, E. P. 1967. Time, work-discipline, and industrial capitalism. Past and present, 56-97.

Thompson, P. 1990. Crawling from the wreckage: The labour process and the politics of production, in Knights, D. and H. Willmott op cit.

Thompson, P. and C. Smith. (Eds) 2010. Working life: Renewing Labour Process Analysis. London: Palgrave.

Thrift, N. 2002. 'Think and Act Like Revolutionaries': Episodes from the global triumph 
of management discourse. Critical Quarterly, 44(3): 19-26.

Van de Ven, A. H. 1999. The Buzzing, Blooming, Confusing World of Organization and Management Theory: A View from Lake Wobegon University. Journal of Management Inquiry, 8: 118-125.

Van Maanen, J. 1995. Style as Theory. Organization Science, 6(1): 133-143.

Weber, S. 2001. Institution and Interpretation: Expanded edition. Stanford: Stanford University Press.

Westwood, R. \& Clegg, S. 2003. The Discourse of Organization Studies: Dissensus, Politics, and Paradigms. In R. Westwood \& S. Clegg (Eds), Debating Organization: Point-Counterpoint in Organization Studies: 1-42. Oxford: Blackwell.

Whitley, R. 1984. The fragmented state of management studies: Reasons and consequences. Journal of Management Studies, 21(3): 331-348.

Wilson, J. F. (1992). The Manchester Experiment: A History of Manchester Business School, 1965-1990. London: Paul Chapman Publishing.

Wilson, J. F., \& Thomson, A. W. J. (2006). The making of modern management. Oxford University Press. 